\title{
NOTCH2 wt Allele
}

National Cancer Institute

\section{Source}

National Cancer Institute. NOTCH2 wt Allele. NCI Thesaurus. Code C97678.

Human NOTCH2 wild-type allele is located within 1p13-p11 and is approximately $158 \mathrm{~kb}$ in length. This allele, which encodes neurogenic locus notch homolog protein 2, is involved in the mediation of cell-cell signaling. Mutation of the gene is associated with both Alag ille syndrome type 2 and Hajdu-Cheney syndrome. 